\title{
An Analysis of Bicycle Route Choice Preferences in Texas, U.S.
}

\author{
Ipek N. Sener \\ The University of Texas at Austin \\ Department of Civil, Architectural \& Environmental Engineering \\ 1 University Station, C1761, Austin, TX 78712-0278 \\ Phone: (512) 471-4535, Fax: (512) 475-8744 \\ Email: ipek@mail.utexas.edu \\ Naveen Eluru \\ The University of Texas at Austin \\ Dept of Civil, Architectural \& Environmental Engineering \\ 1 University Station C1761, Austin TX 78712-0278 \\ Phone: 512-471-4535, Fax: 512-475-8744 \\ E-mail: naveeneluru@mail.utexas.edu \\ Chandra R. Bhat* \\ The University of Texas at Austin \\ Department of Civil, Architectural \& Environmental Engineering \\ 1 University Station, C1761, Austin, TX 78712-0278 \\ Phone: (512) 471-4535, Fax: (512) 475-8744 \\ Email: bhat@mail.utexas.edu \\ *corresponding author
}




\begin{abstract}
In the U.S., the rise in motorized vehicle travel has contributed to serious societal, environmental, economic, and public health problems. These problems have increased the interest in encouraging non-motorized modes of travel (walking and bicycling). The current study contributes toward this objective by identifying and evaluating the importance of attributes influencing bicyclists' route choice preferences. Specifically, the paper examines a comprehensive set of attributes that influence bicycle route choice, including: (1) bicyclists' characteristics, (2) on-street parking, (3) bicycle facility type and amenities, (4) roadway physical characteristics, (5) roadway functional characteristics, and (6) roadway operational characteristics.

The data used in the analysis is drawn from a web-based stated preference survey of Texas bicyclists. The results of the study emphasize the importance of a comprehensive evaluation of both route-related attributes and bicyclists' demographics in bicycle route choice decisions. The empirical results indicate that travel time (for commuters) and motorized traffic volume are the most important attributes in bicycle route choice. Other route attributes with a high impact include number of stop signs, red light, and cross-streets, speed limits, on-street parking characteristics, and whether there exists a continuous bicycle facility on the route.
\end{abstract}

Keywords: Bicycle route choice analysis, Stated preference modeling, Web-based survey, Panel mixed multinomial logit, On-street parking 


\section{INTRODUCTION}

In the U.S., the increasing automobile dependence of households and individuals has contributed to growing traffic congestion, air quality degradation due to increased mobile source emissions, increased energy consumption, and greater dependency on foreign fuel supplies (see Schrank and Lomax, 2005; EPA, 1999; Litman and Laube, 2002; Jeff et al., 1997; Schipper, 2004). The increasing automobile dependence is evident from the observation that $92 \%$ of U.S. households owned at least one motor vehicle in 2001 compared to about $80 \%$ in the early 1970s (see Pucher and Renne, 2003). Further, household motorized vehicle miles of travel increased $300 \%$ between 1977 and 2001 (relative to a population increase of 30\% during the same period; see Polzin and Chu, 2004). The dependence of U.S. households on the automobile has far-reaching impacts on public health, regional ecosystems health, global climate change, urban livability, economic stability, and energy security (Boyle, 2005; TRB, 2002; U.S. Congress, 1994).

The negative consequences of increasing auto dependency have led regional, state, and federal planning agencies to consider transportation demand management strategies to encourage non-motorized mode use. In this context, bicycling has drawn considerable attention due to its wide array of societal and environmental benefits. For instance, bicycling presents families with an inexpensive mode of transportation relative to automobile travel, can help alleviate traffic congestion and associated negative air quality and energy consumption impacts, and contributes to enhancing bicyclists' physical fitness and public health at large by promoting active lifestyles.. Indeed, an earlier study has indicated that physical inactivity has more serious public health repercussions (such as obesity) than automobile-related health problems (including deaths caused by traffic accidents and air pollution), demanding the attention of both transportation and public health researchers (Sallis et al., 2004).

In spite of the benefits of bicycling, and the efforts of planning agencies to encourage bicycling, only $27.3 \%$ of the driving age public (aged 16 and older) in the U.S. ride a bicycle even once during the summer period (2002 National Survey of Pedestrian and Bicyclist Attitudes and Behaviors). The percentage of regular bicyclists is much smaller. For instance, a study of the 2001 National Household Travel Survey (NHTS) revealed that $0.4 \%$ of individuals used bicycling as a usual commute mode (Polzin and $\mathrm{Chu}, 2005$ ). The low use of bicycling as a mode of transportation is despite the fact that a significant fraction of trips in U.S. urban areas are short-distance trips. According to evidence from the 2001 NHTS, $41 \%$ of all trips in 2001 were 
shorter than 2 miles, and 28\% were shorter than 1 mile (Pucher and Renne, 2003). However, in the U.S., automobiles are used for about $74 \%$ of trips shorter than 2 miles, and about $66 \%$ of trips shorter than 1 mile. While a number of reasons exist for this dominance of automobile use in the U.S. even for short distance trips, including the fact that some of these trips are likely to be chained with other trips in a tour, it is safe to say that lack of good bicycling facilities in urban regions and associated safety considerations contribute as barriers to bicycle use. In fact, Pucher and Dijkstra (2003) compared fatality rates per mile of travel by different modes in the U.S., and concluded that bicyclists' fatality rates were 12 times more than that of car occupants.

It is clear from above that one beneficial avenue of research that may inform strategies to encourage bicycle use is to identify the bicycle facility design attributes that individuals consider important for bicycling, and quantitatively evaluate the trade-offs among these design attributes. In this context, the current study identifies the bicycle facility design attributes that affect bicycle route choice, and evaluates the absolute and relative importance of these attributes. The ultimate objective is to inform the development of guidelines to improve existing bicycle facilities and plan future facilities. To the extent that the effects of bicycle facility design attributes may be moderated by demographic factors, bicyclist demographic characteristics are considered in the study as determinants of bicyclist route choice. Overall, the factors considered to explain bicyclist route choice include (1) bicyclist characteristics (such as age, gender, employment characteristics, bicycling experience, reason of bicycling), (2) on-street parking (such as parking type, parking turnover rate, length of parking area, and parking occupancy rate), (3) bicycle facility type and amenities (such as bicycle lane, wide-outside lane, and facility continuity), (4) roadway physical characteristics (such as roadway grade, number of stop signs, red lights, and cross streets), (5) roadway functional characteristics (such as traffic volume and roadway speed limit), and (6) roadway operational characteristics (such as travel time). A stated preference elicitation approach is adopted in the study.

The remainder of the paper is organized as follows. Section 2 discusses earlier studies undertaken to evaluate bicycle facilities, and positions the current study within this broader context. Section 3 discusses survey data collection procedures. Section 4 outlines the modeling methodology employed for data analysis. Section 5 describes the sample used in the analysis, and presents the empirical results. Finally, Section 6 summarizes the findings from the study, and concludes the paper with policy recommendations. 


\section{EARLIER RESEARCH}

There is a substantial body of literature directly or indirectly examining the effects of bicycle facility design attributes on bicyclist route preferences. These studies may be classified into two broad categories: (1) Aggregate-level studies and (2) Disaggregate-level studies. The aggregatelevel studies focus on analyzing the relationship between bicycle route characteristics and aggregate bicycle use measures on the routes (such as change in number of bicyclists using a bicycle route after improvements), or on drawing inferences from cross-comparing bicycle use levels among cities investing in bicycle infrastructure. Examples of such aggregate-level studies include Clarke, 1992, Nelson and Allen, 1997, Wynne 1992, Denver, 1993, Forester, 1996, Moritz, 1997, Carter et al., 1996, and Copley and Pelz, 1995. Since these studies are conducted at the aggregate level and not at the level of the decision-making agent (the bicyclist in this case), relationships and inferences from such studies may simply represent aggregate statistical correlations with little bearing to the underlying bicyclist behavior (see Kassoff and Deutschman, 1969). The disaggregate-level studies undertake the analysis at the level of individual bicyclists, rather than using aggregate-level dependent variables. Thus, an advantage of using a disaggregate-level analysis framework is that it better captures the fundamental behavioral relationship between bicyclist route preferences and its determinants (see Koppelman and Bhat, 2006 for an extensive discussion). In the rest of this section, we discuss only the disaggregatelevel studies, since these are most relevant for quantifying the relationship between bicycle facility attributes and bicyclist route preferences.

A detailed summary of earlier studies examining the relationship between bicycling route choice determinants and bicycle route preferences is presented in Table 1. The route choice determinants are listed in the six categories of variables identified in the previous section bicyclist characteristics, on-street parking, bicycle facility type and amenities, roadway physical characteristics, roadway functional characteristics, and roadway operational characteristics. Several observations can be drawn from this summary table. First, none of the earlier studies has comprehensively considered all the six categories of variables just identified. Also, all the studies in the table have identified bicycle facility type (whether a bicycle lane or a wide outside lane or a shared-use path) and facility continuity as determinants of bicycle route choice. Second, many earlier studies have employed descriptive analysis techniques to analyze the data collected. A small number of studies have employed regression and multinomial logit models to evaluate the 
trade-offs among route attributes. Third, few studies consider on-street parking as a determinant of bicycle route choice preferences. Even those studies that consider on-street parking do so simply in the context of whether on-street parking is allowed or not. Other potentially important attributes characterizing on-street parking, such as parking type (angled or parallel parking), parking turnover rate, length of parking area, and parking occupancy rate have not been considered. Fourth, few studies consider the impact of directness or travel time to the destination, even though this has been found to be an important factor in bicycle route choice for utilitarian travel (such as for commuting) in the studies that have considered travel time (see Bovy and Bradley 1984, Hunt and Abraham 2006, and Tilahun et al., 2007). Fifth, none of the studies have considered the potential taste (sensitivity) variation across individuals to route attributes due to unobserved individual characteristics (even though some studies consider sensitivity variations across individuals due to observed individual characteristics). For instance, some bicyclists may be very safety conscious (even after controlling for bicycling experience) relative to their observationally equivalent peers, while others may be less safety conscious. This can get manifested in the form of differential sensitivity to motorized traffic volumes in route preferences. Similarly, some commuting bicyclists may be time-conscious, while others may be more time-relaxed (this may hold even after controlling for work flexibility). Such variations can get manifested as differential time sensitivities in route choice decisions. Ignoring the moderating effect of such unobserved individual characteristics can, and in general will, result in inconsistent estimates in nonlinear models (see Chamberlain, 1980 and Bhat, 2001).

The above discussion motivates the focus of the current paper, which is to contribute to the existing literature on bicycle route choice analysis by (1) accommodating a comprehensive set of route facility attributes in bicyclist route choice analysis, and evaluating the trade-offs among the several attributes, (2) focusing on on-street parking characteristics as they impact bicyclist route choice, and (3) employing a multivariate analysis framework for route choice analysis that considers taste (sensitivity) variations across bicyclists due to observed and unobserved individual characteristics. 


\section{DATA SOURCE}

A web-based stated preference survey of Texas bicyclists was used to obtain the data for the current study. In the rest of this section, we first discuss the web-based survey, followed by survey administration details, and finally the survey experimental design.

\subsection{Web-based Bicycle Survey}

We adopted a web-based survey approach to collect information from Texas bicyclists for several reasons. First, the web-based survey is inexpensive to the researcher in terms of disseminating information about the survey, easier for respondents to answer, and environmentally friendly. Second, a web-based survey has a quick turn-around time (in terms of receiving responses), and also saves considerable effort in processing since the data is directly obtained in electronic form. Third, question branching is straightforward to implement in webbased surveys since it is based on an individual's response to earlier questions. That is, only the relevant questions are presented to a respondent. Fourth, the analyst can easily implement stated preference experiments in which the attribute levels are pivoted off an individual's bicycling experience. ${ }^{1}$

\subsection{Survey Administration}

The survey was administered through a web site hosted by The University of Texas at Austin. The survey was designed for the internet, using a combination of HTML, JavaScript and Java programs. HTML and Java script were used to generate the web content to collect information on bicyclist and bicycling characteristics of the respondents, while Java was used to automatically generate and present the attribute levels of the SP experiments based on pivoting off the reported

\footnotetext{
${ }^{1}$ The use of a web-based survey will not provide a representative sample of the population at large. Indeed, coverage bias is the primary limitation of web-based surveys resulting from some population segments not having access to or not informed about the use of the internet (TCRP, 2006). One possible solution to overcome this limitation is to implement a multi-method survey combining a variety of survey methods. But such a survey, in addition to its high-cost characteristics, can result in significant measurement error (i.e. the same question can be answered differently because of the different survey methods; see Dillman, 2000 and TCRP, 2006 for a detailed discussion of this point). On the other hand, a web-based survey is a low-cost approach that is effective when targeting bicyclists, who tend to be quite well educated. Also, the focus of our effort here is on obtaining information from individuals who have had some experience in bicycling, since the objective is to obtain useful information for an objective assessment of bicycle facilities and an analysis of bicycling concerns/reasons. Further, given the focus on bicyclists, the route choice model estimates are valid even though we do not have a representative sample of bicylists. This is due to Manski and Lerman's (1981) result for exogenous samples, which is applicable here because the alternatives in the route choice analysis are unlabelled alternatives constructed by the analyst. In this sense, we do not have a choice-based sample because respondents are not chosen based on their route choice.
} 
travel time for commuting bicyclists (further details of the SP experimental design are provided in the next section). The final survey included 45 questions requiring about 15 minutes. Most questions were in the usual text format of surveys, while the SP scenarios were presented in the form of a table with three columns and five rows (each column representing a hypothetical route, and each row representing a certain level of an attribute; respondents were asked to choose the route they would use from the three routes presented). The survey did not include any pictures or diagrams. The final version of the survey instrument is available on request from the authors.

After the final web survey design was completed, we recruited participants using several different mechanisms. We contacted bicycle groups and bicycle forums in several Texas cities, and asked them to forward to their members. The survey link was also e-mailed to student groups in Texas universities. Further, we disseminated information about the survey to media outlets in Austin (including newspapers and television channels). Finally, the survey information was also circulated with the help of metropolitan planning organizations and Texas Department of Transportation offices.

\subsection{Stated Preference Experimental Design}

The focus of the stated preference experimental design was to contribute toward efficiently estimating the trade-offs among the attributes that influence bicycle route choice. Therefore, we first identified a set of potential determinants of bicycle route choice based on our review of earlier studies, intuitive judgment, and input from Texas Department of Transportation (TxDOT) planners. As indicated in the previous section, parking-related attributes have not been studied adequately in earlier studies, and thus assessing parking effects on route choice was a particular emphasis of the current study. Further, we narrowed the focus of our analysis to route attributes that city planning organizations and state departments are most likely to have influence over in designing and planning bicycle facilities. The final attributes chosen for examination in the current analysis included (by category):

- Bicyclist characteristics - Demographics (age and gender), employment-related characteristics (commute distance, work schedule flexibility), and bicycle use characteristics (reason for bicycling and experience in bicycling).

- On-street parking - Parking type (none, angled, or parallel), parking turnover rate, length of parking area, and parking occupancy rate. 
- Bicycle facility characteristics - On-road bicycle lane (a designated portion of the roadway striped for bicycle use) or shared roadway (a shared roadway open to both bicycle and motor vehicle travel), width of bicycle lane if present or overall roadway width if shared roadway, and bicycle facility continuity.

- Roadway physical characteristics - Roadway grade, and number of stop signs, red lights and cross streets.

- Roadway functional characteristics - Motorized traffic volume and speed limit.

- Roadway operational characteristics - Travel time.

Among the attributes identified above, the bicyclist characteristics (first attribute set) do not form part of the SP experiments. Rather, they are used in the empirical analysis to accommodate variations in sensitivity to the route attributes captured in the remaining five attribute sets listed above. Separate experimental designs are developed for commuter bicyclists (those who bicycle for commuting purposes, some of whom may also bicycle for non-commuting reasons) and noncommuter bicyclists (designated to be those who bicycle only for non-commuting purposes). The identification of respondents into these two bicyclist groups is based on questions before the SP experiments are presented. For commuter bicyclists, the SP experiments are designed to elicit information regarding commuting route choice, while, for non-commuting bicyclists, the SP experiments are designed to elicit information on non-commute purpose route choice. It is important to note here that travel time (the last route attribute listed above) is considered only for the SP experiments presented to commuter bicyclists (since travel time is a non-issue for much of the non-commuting bicycling focused on recreation pursuits).

Overall, there are 11 route attributes for commuting-related SP experiments, and 10 route attributes for non-commuting-related experiments (see Table 2 for a description of the attributes). Since incorporating all these route attributes to characterize routes in the SP experiments makes it overwhelming for respondents, we used an innovative partitioning scheme where only five attributes were used to characterize routes for any single respondent. At the same time, the selection of the five attributes for any individual was undertaken in a carefully designed rotating and overlapping fashion to enable the capture of all variable effects when the responses from the different SP choice scenarios across different individuals are brought together. For each (and all) individuals, parking type (i.e., whether parking is allowed on route, and, if allowed, whether it is parallel parking or angled parking) is a common route attribute included. This 
achieves two purposes. The first is that it places emphasis on parking effects on route choice, the focus of the current paper. The second is that the presence of one common attribute across all SP choice scenarios, along with a careful overlapping design for other attributes, is the key to developing a model that incorporates the effects of all route attributes simultaneously. ${ }^{2}$

Each respondent is presented with four choice questions (or choice experiments) in the survey. Within each choice question, three alternative routes (with different levels of the five route attributes selected for the particular respondent) are presented, and the individual is asked to make a choice of route among the three routes. The route attribute levels of each attribute are carefully developed to be distinct in the perception space of bicyclists (see Table 2). The attribute levels for all the attributes except travel time are predetermined. The travel time levels for each route (for commuting bicyclists) in the SP experiments are designed to be pivoted off the actual commute time by bicycle as reported by the individual. This was done to preserve some amount of realism in presenting alternative routes in the stated choice experiments (for example, an individual who takes 5 minutes presently to get to work by bicycle would find it difficult to evaluate routes in the stated choice experiments that take an hour to work).

All the levels for each of the attributes were tested extensively for reasonability in pilot surveys, and several changes were made before arriving at the final levels. The characteristics of each route in each choice scenario presented to the respondent were developed using a balanced and blocked fractional factorial design comprising four SP questions for each respondent (see Hensher et al., 2005 for a good textbook treatment of SP factorial designs). The design was intended to extract the most amount of information regarding the effects of route attributes on route choice decisions. The design was checked to ensure that there was no clear dominant alternative in any SP question presented to a respondent. Further, we placed an explicit constraint in the SP design to ensure that, when the parking type attribute takes a level of "none" for any route in a choice question, none of the other parking attributes (parking turnover rate, length of parking area, and parking occupancy rate) appear for that route in that choice question. The design also enables the estimation of (1) models more general than the multinomial logit model

\footnotetext{
${ }^{2}$ The rotation and overlapping design generates combination sets of 4 attributes from the full set of attributes minus the parking type attribute that is always considered. For each respondent, one of the quadruplet set of attributes is chosen and used in all SP questions posed for that person. The goal of the rotation and overlapping design scheme is to present each combination set about the same number of times across all respondents so that the impact of each attribute (as well as interaction effects of attributes) can be efficiently captured in estimation. To achieve this, a java based software code is written that randomly assigns one of the four attribute sets to the respondent.
} 
by maintaining factor orthogonality within and between alternatives, and (2) main effects of attributes, as well as all two-way interaction effects of attributes.

\section{ECONOMETRIC MODELLING FRAMEWORK}

In this paper, we formulate a panel mixed multinomial logit (or MMNL) model for the bicycle route choice analysis. The panel MMNL model formulation accommodates heterogeneity across individuals due to both observed and unobserved individual attributes. In the following discussion of the model structure, we will use the index $q(q=1,2, \ldots, Q)$ for the decisionmakers, $i$ for the route alternative $(i=1,2, \ldots, I)$ and $k$ for the choice occasion, i.e. SP choice scenarios for a particular decision-maker, $(k=1,2, \ldots, K)$. In the current study $I=3$ and $K=4$, for all $q$.

In the usual tradition of utility maximizing models of choice, we write the utility $U_{q i k}$ that an individual $q$ associates with the alternative $i$ on choice occasion $k$ as follows:

$$
U_{q i k}=\left(\beta^{\prime}+v_{q}^{\prime}\right) x_{q i k}+\varepsilon_{q i k}
$$

where $x_{q i k}$ is a $(M \times 1)$-column vector of route attributes, and the interactions of route attributes among themselves and with bicyclist characteristics, affecting the utility of individual $q$ for alternative $i$ at the $k^{\text {th }}$ choice occasion. $\beta$ is a corresponding $(M \times 1)$-column vector of the mean effects of the coefficients of $x_{q i k}$ on route choice propensity, and $v_{q}$ is another $(M \times 1)$-column vector with its $m^{\text {th }}$ element representing unobserved factors specific to individual $q$ and her/his trip environment that moderate the influence of the corresponding $m^{\text {th }}$ element of the vector $x_{q i k}$. A natural assumption is to consider the elements of the $v_{q}$ vector to be independent realizations from a normal population distribution; $v_{q m} \sim N\left(0, \sigma_{m}^{2}\right) . \quad \varepsilon_{q i k}$ represents a choice-occasion specific idiosyncratic random error term assumed to be identically and independently standard Gumbel distributed. $\varepsilon_{q i k}$ is assumed to be independent of $x_{q k}$. In the current context, we do not have any alternative specific variables since the route alternatives are "unlabeled" and characterized by route attributes.

For a given value of the vector $v_{q}$, the probability that individual $q$ will choose route $i$ at the $k^{\text {th }}$ choice occasion can be written in the usual multinomial logit form (McFadden, 1978): 


$$
P_{q i k} \mid v_{q}=\frac{e^{\beta^{\prime} x_{q i k}+v_{q}^{\prime} x_{q i k}}}{\sum_{j=1}^{I} e^{\beta^{\prime} x_{q j i}+v_{q}^{\prime} x_{q i k}}}
$$

The unconditional probability can then be computed as:

$$
P_{q i k}=\int_{v_{q}}\left(P_{q i k} \mid v_{q}\right) d \boldsymbol{F}\left(v_{q} \mid \sigma\right)
$$

where $\boldsymbol{F}$ is the multivariate cumulative normal distribution and $\sigma$ is a vector that stacks up the $\sigma_{m}$ elements across all $m$ (we assume independence of the elements of $v_{q}$ ). The reader will note that the dimensionality in the integration above is dependent on the number of elements in the $v_{q}$ vector.

The parameters to be estimated in the model of Equation (3) are the $\beta$ and $\sigma$ vectors. To develop the likelihood function for parameter estimation, we need the probability of each individual's sequence of observed SP choices. Conditional on $v_{q}$, the likelihood function for individual $q$ 's observed sequence of choices is:

$$
L_{q}\left(\beta \mid v_{q}\right)=\prod_{k=1}^{K}\left[\prod_{i=1}^{I}\left\{P_{q i k} \mid v_{q}\right\} \delta_{q i k}\right] \text {, }
$$

where $\delta_{q i k}$ is a dummy variable taking the value of 1 if the $q^{\text {th }}$ individual chooses the $i^{\text {th }}$ route in the $k^{\text {th }}$ occasion, and 0 otherwise. The unconditional likelihood function for individual $q$ 's observed set of choices is:

$$
L_{q}(\beta, \sigma)=\int_{v_{q}} L_{q}\left(\beta \mid v_{q}\right) d F\left(v_{q} \mid \sigma\right)
$$

The log-likelihood function is $L(\beta, \sigma)=\Sigma_{q} \ln L_{q}(\beta, \sigma)$. We apply quasi-Monte Carlo simulation techniques to approximate the integrals in the likelihood function and maximize the logarithm of the resulting simulated likelihood function across all individuals with respect to the parameters $\beta$ and $\sigma$. Under rather weak regularity conditions, the maximum (log) simulated likelihood (MSL) estimator is consistent, asymptotically efficient, and asymptotically normal (see Hajivassiliou and Ruud, 1994; Lee, 1992; McFadden and Train, 2000).

In the current paper, we use Halton sequences to draw realizations for $v_{q}$ from its assumed normal distribution. Details of the Halton sequence and the procedure to generate this sequence are available in Bhat $(2001,2003)$. 


\section{EMPIRICAL ANALYSIS}

\subsection{Sample Formation and Variable Specification}

Several screening steps were undertaken to ensure the completeness and consistency of the respondent's survey, including removing the records of respondents who provided incomplete information and checking the reported commute distance traveled, reported bicycle travel times, and the ratios of the reported bicycle travel times versus the reported auto commute travel times.

The final estimation sample used in the empirical modeling of bicycle route choice included 6484 choice occasions from 1621 individuals. Of the 1621 individuals, 814 (50.2\%) respondents use their bicycle for commuting and are designated as commuter bicyclists in the current study (801 of these 814 commuter bicyclists also bicycle for non-commuting purposes such as running errands, exercising, visiting friends or family, recreation, and racing/stuntriding). The remaining 807 individuals (49.8\%) bicycle only for non-commuting purposes, and are designated as non-commuting bicyclists in the current study. The details of the demographic composition and other bicycling characteristics are being suppressed here because of space considerations, but may be found in Torrance et al., 2007. Overall, the bicyclist sample from our survey is skewed slightly more toward males and away from young adults compared to national figures from the National Survey of Pedestrian and Bicyclist Attitudes and Behaviors (2002). ${ }^{3}$ However, there are no tangible differences in such commute characteristics as travel time and travel distance among those who bicycle to work.

The route choice model estimated in this study considered the five sets of route attributes identified earlier (see Table 2), interaction effects of the route attributes with bicyclist characteristics, and several interaction effects of the route attributes. The final variable specification was obtained based on a systematic process of eliminating variables found to be statistically insignificant and parsimony in representing variable effects.

\subsection{Empirical Results}

The effects of route attributes and related interaction effects are presented in Table 3 and discussed in the following sections by route attribute category. The parameters provide the effect of variables on the utility valuation of routes. Interaction effects of route attributes with any

\footnotetext{
${ }^{3}$ The split between females and males in our sample (national sample) is $71 \%$ to $29 \%$ (62\% to $38 \%$ ). The percentage of individuals in the 18-24 years range in our sample is $11 \%$, while the percentage in the 16-24 years range in the national sample is $24 \%$ (the age groups used are different between the two samples, and so a perfect comparison is not possible).
} 
bicyclist characteristics are shown in Table 3 by indenting the labels for bicyclist characteristics under the route attributes. Interestingly, while we attempted several interactions among route attributes, none of these turned out to be statistically significant, except for the interaction effect of heavy motorized traffic volume and a continuous bicycle facility.

\subsubsection{On-street parking characteristics}

In the group of on-street parking characteristics, the effect of parking type is introduced by including variables associated with angled parking and parallel parking, and their interactions with other variables (the absence of parking serves as the base category). Thus, the first numerical cell value of -0.422 in Table 3 indicates that, on average, a route with parallel parking is 0.422 utility units less attractive than a route with no parking for a female non-commuter bicyclist older than 24 years (and also for a female commuter bicyclist older than 24 years and commuting less than 5 miles). However, for a male bicyclist with the same characteristics, a route with parallel parking is $0.547(=0.422+0.125)$ utility units less attractive than a route with no parking. The signs and magnitudes of the parking type-related effects reveal several important results. First, regardless of their personal and trip circumstances, all bicyclists prefer no parking to any form of parking on their route. This is intuitive, since parking reduces sight distance, presents a hindrance to bicycle movement, and poses a safety threat. Second, all bicyclists except young adults (18-24 years of age) prefer angled parking to parallel parking, except young adults (18-24 years of age) who are indifferent between angled and parallel parking. The angled configuration provides a little more maneuvering room for bicyclists and provides more time to react since bicyclists can better see cars backing out. On the other hand, a parallel configuration leads to a higher duration of "conflict exposure" when motorists are backing into a parallel parking spot. Besides, bicyclists are particularly vulnerable to "dooring" problems as motorists get into/out of their vehicles in a parallel parking configuration. Third, male bicyclists are more likely than female bicyclists to stay away from routes on which parking is allowed. This may be a manifestation of male bicyclists traveling at higher speeds (see Helgerud et al., 1990). Finally, the parking type effects also indicate that parking is more of a deterrent in route choice for long commute trips (distance $>5$ miles) relative to short commute trips and non-commute trips. This is possibly related to the duration of constant (and draining) vigility that is needed for long distance commutes on routes with parking. 
The remaining on-street parking variables "switch on" conditional on the parking type being parallel or angled parking. Overall, the results show that bicyclists (and especially female bicyclists) shy away from routes where they are likely to encounter vehicles leaving parking spots. This suggests that, at least on bicycle routes, some consideration should be given to relax or remove time-restricted parking limits (such as 30 minute parking or 1 hour parking). The results of the last two on-street parking-related variables in Table 3 reinforce the general notion that bicyclists prefer routes with less parking activity (if they have to choose among routes with parking). Specifically, when parking is present, bicyclists prefer shorter lengths of parking area and lower parking occupancy rates along their routes. It is also interesting to note here that bicyclists prefer routes with long parking lengths and moderate parking occupancy rates relative to routes with moderate parking lengths and high parking occupancy rates.

Interaction effects of parking characteristics with bicyclist experience, bicycle facility characteristics, and roadway physical/functional characteristics were also considered, but surprisingly none of these other interaction effects came out to be statistically significant. The implication is that parking characteristics do not differentially impact bicyclist route choice based on bicyclist experience and bicycle facility/roadway characteristics.

\subsubsection{Bicycle facility characteristics}

Two attributes are used to capture bicycle facility characteristics. The first is whether the bicycle facility is a bicycle lane (a designated portion of the roadway striped for bicycle use) or not (i.e., is a shared roadway open to both bicycle and motor vehicle travel), and corresponding facility widths. This attribute is captured in the form of four dummy variables, with the base category being the presence of a 3.75 feet bicycle lane (equivalent to 1.5 bicycle widths). The four dummy variables are: (1) presence of a 6.25 feet bicycle lane (equivalent to 2.5 bicycle widths), (2) no bicycle lane and a 10.5 feet wide outside lane (equivalent to 1.5 car widths), (3) no bicycle lane and a 14.0 feet wide outside lane (equivalent to 2 car widths), and (4) no bicycle lane and a 17.5 feet wide outside lane (equivalent to 2.5 car widths). The second attribute within the category of bicycle facility characteristics is bikeway continuity, indicating whether or not the bicycle lane or wide outside lane is continuously available along the route.

The findings in Table 3 show no statistically significant differences in preferences between a 3.75 feet bicycle lane and a 6.25 feet bicycle lane (and so both of these levels form the 
base category). Further, the results indicate that bicyclists actually prefer a general purpose lane to a bicycle lane. While this result may seem counterintuitive, it may be reflecting a preference of bicyclists to have more maneuvering room by not being "boxed" into a bicycle lane and having the psychological freedom to go around vehicles/objects as needed. Our result may also be associated with the concept of vehicular bicycling (Forester, 1993; 1994), which is based on the notion that motorists should be educated to treat bicyclists as lawful users of roadways. Proponents of vehicular bicycling oppose bicycle lanes on the grounds that it "promotes the belief that bicyclists are not legitimate users of ordinary roads" (see Pucher et al., 1999). However, this result may also be related to the fact that many respondents in the survey are drawn from bicycle group list serves and are bicycle enthusiasts with a "road warrior" mentality. Also, it should be noted that the result here is confined to current bicyclists. It is possible that non-bicyclists would be more willing to bicycle if there is a bicycle lane rather than a wide outside lane (see Wilkinson et al., 1994).

The positive coefficient corresponding to the continuous bicycle facility dummy variable clearly underscores the preference among bicyclists for a continuous bicycle facility, especially for long commute trips (see Stinson and Bhat, 2003, and Antonakos, 1994 for a similar result). The results also show that, as expected, the benefit of a continuous facility relative to a discontinuous facility is not as strong in the presence of parallel parking as in the absence of parallel parking. This is because the presence of parallel parking effectively leads to a "discontinuous-like" path due the intrusion of vehicles in the movement space of bicyclists.

\subsubsection{Roadway physical characteristics}

The positive sign on "moderate hills" indicates a mean preference for slightly hilly terrain (compared to flat terrain), especially for non-commuting bicycling. This trend may be attributed to the preference for a bicycle route that is not monotonous in landscape or physical effort, especially for bicyclists undertaking bicycling for recreation/leisure (see Stinson and Bhat, 2003 for similar results). However, there is high and statistically significant unobserved variation in the sensitivity to moderate hills. The coefficient estimates and the standard deviation estimate suggest that, among commuting bicyclists, $63 \%$ prefer moderate hills to a flat riding surface, while $37 \%$ prefer a flat riding surface to a moderate hill surface. The corresponding estimates for non-commuting bicyclists are $81 \%$ and $19 \%$, respectively. 
The coefficients on "steep hills" and its interaction terms indicate the following general route choice trends: (1) female bicyclists commuting to work avoid routes with steep hills, (2) male bicyclists commuting to work marginally prefer routes with steep hills to those with flat terrains, but prefer routes with moderate hills to steep hills, (3) female bicyclists riding a bicycle for non-commuting purposes are indifferent between routes with steep hills and flat terrains, but prefer routes with moderate hills to both the flat and steep hill extremes, and (4) male bicyclists riding a bicycle for non-commuting purposes have a statistically significant preference for routes with steep hills over moderate hills, and for moderate hills over flat terrains. Overall, these gender differences in preference for terrain grade may be associated with the higher inclination for physical activity among men relative to women (see, for instance, Bhat and Lockwood, 2004 and Lawrence and Engelke, 2007). Of course, the statistically significant estimate on the standard deviation corresponding to the "steep hills" variable also indicates substantial unobserved heterogeneity in preferences among bicyclists for steep hills.

The final variable in the category of roadway physical characteristics clearly reflects the reduced likelihood of using routes with a higher number of traffic controls and cross-streets, though males and experienced bicyclists are not as bothered by traffic controls/cross-streets as are females and inexperienced bicyclists, respectively.

\subsubsection{Roadway functional characteristics}

The level of motorized traffic volume and the speed limit are used to represent roadway functional characteristics. As expected, bicyclists, in general, prefer routes with a lower traffic volume. This is particularly so for men (relative to women) and bicyclists commuting to work. Bicyclists commuting long distances are especially sensitive to heavy traffic volumes, possibly because of the longer duration of exposure to traffic and related safety concerns. Also, routes that combine a discontinuous facility with heavy traffic increase conflict points and accident hazards, and are not favorably evaluated by bicyclists. There is also substantial variation in how bicyclists respond to traffic volume conditions, depending on unobserved personality traits (for example, some bicyclists may be less concerned about riding with traffic, while others may be paranoid and claustrophobic with traffic around).

The results corresponding to the speed limit variables show a preference for roadways with lower speed limits, though this preference is tempered for individuals experienced in 
bicycling and for long distance commuting. In fact, the results show that experienced bicyclists commuting long distances (who are likely also to be health conscious individuals) prefer moderate speed limit routes to low speed limit routes, perhaps because they are comfortable riding with vehicles traveling at a moderate speed and see a health benefit from being able to ride at relatively high speeds. However, even these individuals avoid high speed limit roads, because of the substantially increased safety hazard.

\subsubsection{Roadway operational characteristics}

The final set of variables in Table 3 corresponds to travel time effects, which are relevant only for commute-related route choice. The coefficient on the travel time variable is negative and highly significant, reflecting a preference for shorter commute travel times. The results also show that young bicyclists (18-34 years) are more sensitive to travel time than are older bicyclists (35 years or over), perhaps because of a more fast-paced lifestyle among the young. Finally, there is a relatively high variation in the sensitivity to travel time due to unobserved factors (for example, some individuals may be dynamic "go-getters" who value time substantially, while others may be peaceful "bigger-life" picture-oriented individuals who enjoy their time bicycling to work). The magnitude of the travel time coefficients relative to the standard deviation estimate implies a negative effect of travel time for $80 \%$ of individuals who are 35 years or older. This percentage increases to $93 \%$ for individuals who are younger than 35 years.

\subsection{Relative Effects of Route Attributes}

The coefficients in Table 3 can also be used to examine the relative magnitudes of the effects of route attributes on route choice. This is because all route attributes in the model are dummy (discrete) variables (or switches), except for travel time for commute-related route choice. While one cannot technically compare the relative effects of the dummy variables and the travel time variable for commute-related route choice, one approach to get an order of magnitude effect is to compute the (dis-)utility effect of travel time at the mean commute travel time value of 30 minutes in the sample. This yields a value of -2.04 , which may be compared with the coefficients on the route attribute dummy variables.

As indicated in the previous section, the effects of route attributes is moderated by bicyclist characteristics (age, gender, and bicycling experience) and bicycling characteristics 
(purpose of bicycling and commute distance). But, in the overall, the magnitudes of the coefficients in Table 3 indicate that travel time (for commuters) and heavy traffic volume are the most important attributes in bicycle route choice. Other route attributes with a high impact include number of stop signs, red light, and cross-streets (especially for individuals with relatively less experience in bicycling), high speed limits (especially for individuals with little experience in bicycling and who commute short distances), on-street parking characteristics (especially high parking occupancy rate, high parking turnover for women, and length of parking area), and whether there exists a continuous bicycle facility on the route. On the other hand, bikeway width (if a bike lane exists) or width of wide outside lane (if bike lane does not exist) is the least important attribute in bicyclist route choice evaluation, while the impact of terrain grade is also quite small.

Another illustrative approach to undertake a valuation of route attributes is in the context of how much bicyclists are willing to pay for improvements in route attributes. One can obtain such a willingness to pay measure in terms of the amount of extra travel time and money that bicyclists are willing to incur to travel on an improved route with a given origin and destination. Table 4 provides the results of the time and money-based trade-off analysis by commute distance for commuter bicyclists (we are providing the trade-offs only for commuter bicyclists because travel time is a relevant factor only for such bicyclists). ${ }^{4}$ The time values in Table 4 are obtained in a straightforward manner from the model coefficients, while the money values are obtained by applying a money value of time of $\$ 12.19$ per hour (as obtained in Bhat and Sardesai (2006) for the Austin, Texas commute context) to the time value of each bicycle route attribute. The positive time (or money) values in the table indicate how much additional travel time (money) bicyclists would be willing to travel (pay) to avoid the corresponding attribute on their route, while negative values indicate how much additional travel time (or money) bicyclists would be willing to travel (pay) to have the corresponding attribute on their route. For instance, the first numerical cell value of 6.21 minutes indicates that short commute distance bicyclists would be willing to bicycle about 6.21 more minutes or pay $\$ 1.26$ to avoid parallel parking on their bicycle commute route. The results in Table 4 indicate that the time and money values of attributes are very similar for long and short commute distance bicyclists. The exceptions are for parking type

\footnotetext{
${ }^{4}$ Strictly speaking, these trade-offs with respect to time (and money) are a function of age and gender too, but we aggregate over age and gender for the trade-off computations in Table 4 by assuming the age split and gender split as obtained in our sample.
} 
(long distance commuting bicyclists are more sensitive to both parallel and angle parking than short distance commuting bicyclists), continuous bicycle facility (long distance commuting bicyclists are willing to pay more for a route with no parking than short distance commuting bicyclists), traffic volume (long distance commuting bicyclists are willing to pay more to travel on a route with less heavy motorized traffic than short distance commuting bicyclists), and speed limit (short distance commuting bicyclists are willing to pay more for a route with lower speed limit on the roadway than short distance commuting bicyclists). Further, consistent with the relative magnitude of variable effects discussed earlier, traffic volume corresponds to the attribute for which commuting bicyclists are willing to pay the highest time and/or money for an improvement. Specifically, short distance commuting bicyclists are willing to travel (pay) about 31 minutes (\$6) more for a route with light or moderate traffic, while the corresponding time and money values for long distance commuting bicyclists are even higher (i.e. about 39 minutes and $\$ 8$, respectively). In addition, bicyclists would be willing to travel (pay) a considerable amount of time (money) to avoid (for improvements in) other attributes, such as number of stop signs, red lights and cross streets on the route, parking occupancy rate, and length of parking area.

\subsection{Likelihood-Based Measures of Fit}

The log-likelihood value at convergence of the final mixed multinomial logit (MMNL) model with interactions is -5277.85 . The corresponding log-likelihood value at convergence of the simple multinomial logit (MNL) model without the unobserved individual heterogeneity terms is -5403.75. The likelihood ratio test value for comparing the MMNL model with the MNL model is 251.80 , which is much higher than the critical chi-square value with 3 degrees of freedom at any reasonable level of significance. This clearly indicates the presence of unobserved individual factors that influence the sensitivity to roadway terrain, traffic volumes, and speed limits in bicyclist route choice decisions. Additionally, the log-likelihood value at convergence for the model without any explanatory variables or unobserved heterogeneity is -5488.33 . A likelihood ratio test between our final specification and the model without any explanatory variables or unobserved heterogeneity is 420.96 , which is again much higher than the critical chi-squared value with 23 degrees of freedom at any reasonable level of significance. This underscores the value of the model estimated in this paper to explain route choice as a function of route attributes and their interactions with bicyclist characteristics. 


\section{CONCLUSION}

This paper presents a model for evaluating bicycle route choice preferences. The study contributes to the existing literature in three ways. First, the study undertakes a comprehensive

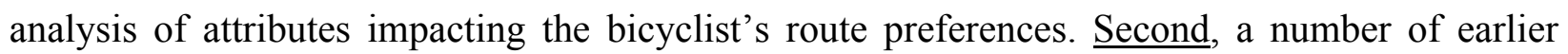
studies have employed descriptive analysis to study the influence of attributes on bicycle route choice. The current study employs a multivariate analysis of the attributes that influence bicycle route choice. Third, on-street parking attributes are very often not considered in bicycle route choice analysis. In the current research, we consider presence of parking and a variety of parking related attributes, including parking turnover rate, length of parking area and parking occupancy rate.

A stated preference methodology was adopted in this study using a web-based survey to gather data from bicyclists in Texas. The results of the empirical analysis offer several important insights. The study results underscore the influence of on-street parking on bicycle route choice. Specifically, the results indicate that bicyclists prefer routes with no parking along the route. Among the routes with parking, bicyclists prefer routes with angle parking. Parking related attributes and their interactions considered in the study also emphasize the preference of bicyclists for minimal parking along the route. Further, the study highlights the preference for continuous bicycle facilities, lower traffic volume, and lower roadway speed limit as well as less number of stop signs, red lights and cross streets on their route. Another interesting observation from the analysis is the bicyclist preference for moderate hills over flat terrain. Finally, the analysis clearly emphasizes the sensitivity of commuting bicyclists to travel time. Of course, it is important to note that the results in this paper are based on a Texas survey, and may not be directly transferable to bicyclist route choice behavior in other parts of the country and/or in other parts of the world. Additional studies of route choice behavior in different contexts and using different data collection approaches are needed to develop a knowledge base for bicycle facility planning and design. Further, the research presented in the paper would benefit from additional human factor/traffic safety explorations. But this paper contributes to the literature on bicycle route choice behavior and provides guidance for bicycle facility planning, while also underscoring the need to consider both route-related attributes and bicyclists' demographics in bicycle route choice preferences. 
An appealing output from the analysis is an estimate of how much additional travel time (money) bicyclists would be willing to travel (pay) to avoid undesirable route attributes, as well as how much additional travel time (money) bicyclists would be willing to travel (pay) to have desirable route attributes. These estimates can be used for cost-benefit evaluations of bicycle route improvements. In addition, the model developed in this paper can be applied in at least four other ways to inform bicycle facility policy and design, as discussed in turn in the next four paragraphs

The first type of application of the model can be to assess and improve the existing bicycle routes as well as to plan better routes. For instance, assume that a planner needs to decide the best bicycle route (or the most attractive route) among the following two routes between an origin and a destination. The first route is a moderately hilly shared roadway with a 14 feet wide outside lane, on which parking is not allowed. It includes more than 5 stop signs, red lights, and cross streets, and the roadway speed limit is greater than $35 \mathrm{mph}$. Further, the travel time to destination for commuter bicyclists is 25 minutes. On the other hand, the second route is a steep shared roadway with a 16 feet wide outside lane, on which parallel parking is allowed. There is a $60 \%$ chance of encountering a vehicle leaving a parking spot. The parking area is $2-4$ city blocks long, and the parking occupancy rate is 26-75\%. It includes 1-2 stop signs, red lights, and cross streets, and the roadway speed limit is less than $20 \mathrm{mph}$. Finally, the travel time to destination for commuter bicyclists is 15 minutes. At first glance, it is not clear which route may be more desirable to bicyclists because each route exhibits some attributes that are better than the corresponding attributes of the other route. For example, from the standpoint of parking attributes, the first route is a better option since parking is not permitted on the route. However, from a roadway speed limit standpoint, the second route is better since the speed limit is less than $20 \mathrm{mph}$ compared to more than $35 \mathrm{mph}$ on the first route. In this context, our results indicate that the overall utility of the second route is higher than the utility of the first route, i.e., the second route is more desirable than the first route.

A second application for the model would be to evaluate the potential increase in demand in response to improvements on a bicycle route. For example, the results of our study suggest a $33 \%$ increase in bicyclist patronage due to a reduction of travel time from 25 to 20 minutes for the first route identified above. 
A third application of the model is to identify trade-offs among route attributes. Consider, for example, that, due to accessibility considerations for motorized traffic, it has been decided to allow angled parking over 2-4 city blocks of the first route. Also, assume that there will be a 30\% parking turnover rate and a 26-75\% parking occupancy rate. Our results indicate that this change will discourage bicyclists to use this route. Based on the utility calculations, our results show that planners can make the route at least as appealing as earlier by reducing the travel time to 20 minutes and reducing the roadway speed limit on the route to 20-35 $\mathrm{mph}$.

Finally, the estimation results of this study can play an important role in developing effective policy initiatives targeted at each of several bicyclist groups. For instance, our results indicate that, while commuter bicyclists can be attracted by reducing travel time, non-commuter bicyclists can be encouraged by providing routes along roadways that have moderate and steep hills.

\section{ACKNOWLEDGEMENTS}

The research in this paper was funded by a Texas Department of Transportation (TxDOT) project entitled "Operational and Safety Impacts for Bicyclists Using Roadways with On-Street Parking". The authors would like to thank the project monitoring committee of TxDOT Project 0-5755 for their input and suggestions during the course of the TxDOT project. Four reviewers and Editor-in-Chief, Martin Richards, provided valuable feedback on an earlier version of the paper. Lisa Macias helped with formatting and typesetting the document. Finally, the first author would like to dedicate her part of the research efforts to her beloved grandmother, Nese Nihal Ozsoy, who passed away in October 2008. 


\section{REFERENCES}

Antonakos CL (1994) Environmental and travel preferences of cyclists. Transportation Research Record 1438: 25-33.

Aultman-Hall LM (1996) Commuter bicycle route choice: analysis of major determinants and safety implications. Ph.D. Thesis, McMaster University, Hamilton, ON.

Axhausen KW, Smith RL (1986) Bicyclist link evaluation: a stated-preference approach. Transportation Research Record 1085: 7-15.

Bhat CR (2001) Quasi-random maximum simulated likelihood estimation of the mixed multinomial logit model. Transportation Research Part B 35: 677-693.

Bhat CR (2003) Simulation estimation of mixed discrete choice models using randomized and scrambled Halton sequences. Transportation Research Part B 37(9): 837-855.

Bhat CR, Lockwood A (2004) On distinguishing between physically active and physically passive episodes and between travel and activity episodes: an analysis of weekend recreational participation in the San Francisco bay area. Transportation Research Part A 38: 573-592.

Bhat CR, Sardesai R (2006) The impact of stop-making and travel time reliability on commute mode choice. Transportation Research Part B 40(9): 709-730.

Bovy P, Bradley M (1984) Route choice analyzed with stated-preference approaches. Transportation Research Record 1037: 11-20.

Boyle G (2005) An overview of alternative transport fuels in developing countries: drivers, status, and factors influencing market deployment, hydrogen fuel cells and alternatives in the transport sector: issues for developing countries. United Nations University International Conference, Maastricht, Netherlands.

Calgary (1993) Calgary commuter cyclist survey 1992/1993; final results. City of Calgary Transportation Department, Calgary AB, Canada.

Carter C, Rickman M, Snelson P, Morgan J, Grimshaw J, Treadgold P (1996) The future for cycling. Report of a Half-Day Meeting, 7 June 1996. Proceedings of the Institution of Civil Engineers, Transport 117(3): 231-233.

Chamberlain G (1980) Analysis of covariance with qualitative data. Review of Economic Studies 47: 225-238.

Clarke A (1992) Bicycle-friendly cities: key ingredients for success. Transportation Research Record 1372: 71-75.

Copley JD, Pelz DB (1995) The city of Davis experience - what works. In: Lall BK, Jones Jr. DL (eds) Transportation Congress: Civil Engineers - Key to the World's Infrastructure, Vol. 2, American Society of Civil Engineers, New York, pp 1116-1125.

Davis WJ (1995) Bicycle test route evaluation for urban road conditions. In: Lall BK, Jones Jr. DL (eds) Transportation Congress: Civil Engineers - Key to the World's Infrastructure, Vol. 2, American Society of Civil Engineers, New York, pp 1063-1076.

Denver (1993) Denver bicycle master plan. City and County of Denver, Denver, CO.

Dillman DA (2000) Mail and internet surveys: the tailored design method. John Wiley \& Sons, Inc., New York.

EPA (1999) Indicators of the Environmental Impacts of Transportation. Report EPA 230-R-99001, US Environmental Protection Agency.

Forester J (1993) Effective cycling, $6^{\text {th }}$ edn. The MIT Press, Cambridge, MA.

Forester J (1994) Bicycle Transportation, $2^{\text {nd }}$ edn. The MIT Press, Cambridge, MA. 
Forester J (1996) How to make biking a real alternative. Transportation and Environment 21: 5961.

Guttenplan M, Patten R (1995) Off-road but on track. Transportation Research News 178(3): 711.

Harris and Associates (1991) Pathways for people. Rodale Press Survey, Emmaus, PA.

Hajivassiliou VA, Ruud PA (1994) Classical estimation methods for LDV models using simulations. In: Engle R, McFadden D (eds) Handbook of Econometrics IV. Elsevier, New York, pp 2383-2441.

Helgerud J, Ingjer F, Stremme SB (1990) Sex differences in performance-matched marathon runners. European Applied Journal of Physiology and Occupational Physiology 61, 433-439.

Hensher DA, Rose JM, Greene WH (2005) Applied choice analysis. Cambridge University Press, Cambridge.

Hopkinson P, Wardman M (1996) Evaluating the demand for new cycle facilities. Trans. Pol 3(4): 433-439.

Hunt JD, Abraham JE (2006) Influences on bicycle use. Transportation, 34(4): 453-470

Jeff K, Laube F, Newman P, Barter P (1997) Indicators of transport efficiency in 37 global cities. A Report to The World Bank, pp 44.

Kassoff H, Deutschman HD (1969) Trip generation: a critical appraisal. Highway Research Record 297: 15-30.

Koppelman FS, Bhat CR (2006) A self instructing course in mode choice modeling: multinomial and nested logit models. Prepared for U.S. Department of Transportation Federal Transit Administration.

Landis BW, Vattikutti VR, Brannick M (1997) Real-time human perceptions: towards a bicycle level of service. Transportation Research Record 1578: 119-126.

Lawrence DF, Engelke P (2007) How land use and transportation systems impact public health: a literature review of the relationship between physical activity and built form. ACES Working Paper \# 1. Available online at: http://www.cdc.gov/nccdphp/dnpa/pdf/acesworkingpaper1.pdf. Accessed July 25, 2007.

Lee L-F (1992) On the efficiency of methods of simulated moments and maximum simulated likelihood estimation of discrete response models. Econometric Theory 8: 518-552

Litman T, Laube F (2002) Automobile dependency and economic development. Victoria Transport Policy Institute, Canada.

Lott DY, Tardiff T, Lott DF (1978) Evaluation by experienced riders of a new bicycle lane in an established bikeway system. Transportation Research Record 683: 40-46.

Manski C, Lerman S (1981) On the use of simulated frequencies to approximate choice probabilities. In Manski C, McFadden D (eds) Structural analysis of discrete data with econometric applications. MIT Press, Cambridge, MA, pp 305-319.

McFadden D (1978) Modeling the choice of residential location. In: Karlquist A, Lundquist L, Snickbars F, Weibull JW (eds) Spatial Interaction Theory and Planning Models. NorthHolland, Amsterdam.

McFadden D, Train K (2000) Mixed MNL models of discrete response. Journal of Applied Econometrics 15: 447-470.

Moritz, WE (1997) A survey of North American bicycle commuters - design and aggregate results. Presented at the 76th Annual Meeting of the Transportation Research Board, Washington DC. 
National Survey of Pedestrian and Bicyclist Attitudes and Behaviors (2002) Sponsored by the U.S. Department of Transportation's National Highway Traffic Safety Administration and the Bureau of Transportation Statistics. Available online at: http://www.bts.gov/programs/omnibus_surveys/targeted_survey/2002 national_survey_of_pe destrian and bicyclist attitudes and behaviors/survey highlights/entire.pdf

Nelson AC, Allen D (1997) If you build them, commuters will use them: the association between bicycle facilities and bicycle commuting. Transportation Research Record 1578: 79-83.

Ortúzar J de D, Iacobelli A, Valeze C (2000) Estimating demand for a cycle-way network. Transportation Research Part A 34(5): 353-373.

Polzin SE, Chu X (2004) Travel behavior trends: the case for moderate growth in household vmt- evidence from the 2001 NHTS. Working paper, Center for Urban Transportation Research, University of South Florida, Tampa, FL.

Polzin, SE, Chu X (2005) Public transit in America: results from the 2001 national household travel survey. National Center for Transit Research, Center for Urban Transportation Research, University of South Florida, Tampa, FL.

Pucher J, Komanoff C, Schimek P (1999) Bicycling renaissance in North America? Recent trends and alternative policies to promote bicycling. Transportation Research Part A 33: 625654.

Pucher J, Dijkstra L (2003) Promoting safe walking and cycling to improve public health: lessons from the Netherlands and Germany. American Journal of Public Health 93: 15091516.

Pucher J, Renne JL (2003) Socioeconomics of urban travel: evidence from the 2001 NHTS. Transportation Quarterly 57(3): 49-77.

Sacks DW (1994) Greenways as alternative transportation routes: a case study of selected greenways in the Baltimore, Washington area. M.Sc. Thesis, Towson State University, Towson, MD.

Sallis, JF, Frank LD, Saelens BE, Kraft MK (2004) Active transportation and physical activity: opportunities for collaboration on transportation and public health research. Transportation Research Part A 28(4): 249-268.

Schipper MA (2004) Supplemental data for 2001 NHTS. Presented at the $83^{\text {rd }}$ Annual Meeting of the Transportation Research Board, Washington DC.

Schrank D, Lomax T (2005) The 2005 urban mobility report. Texas Transportation Institute, The Texas A\&M University System, College Station. Available at: http://mobility.tamu.edu

Stinson MA, Bhat CR (2003) An analysis of commuter bicyclist route choice using a stated preference survey. Transportation Research Record 1828: 107-115.

Tilahun N, Levinson D, Krizek K (2007) Trails, lanes, or traffic: the value of different bicycle facilities using an adaptive stated preference survey. Transportation Research Part A 41(4): 287-301.

Torrance K, Sener IN, Machemehl R, Bhat CR, Hallett I, Eluru N, Hlavacek I, Karl A (2007) The effects of on-street parking on cyclist route choice and the operational behavior of cyclists and motorists. Draft report 0-5755-1, Center for Transportation Research, The University of Texas at Austin.

Transit Cooperative Research Program (TCRP) (2006) Web-based survey techniques, a synthesis of transit practice. Transportation Research Board, Washington DC. 
Transportation Research Board (2002) Surface transportation environmental research: a longterm strategy. Special Report 268, Surface Transportation Environmental Cooperative Research Program Advisory Board, National Research Council.

U.S. Congress (1994) Saving energy in U.S. transportation. OTA-ETI-589, Office of Technology Assessment, U.S. Government Printing Office, Washington DC, July.

Wilkinson W, Clarke A, Epperson B, Knoblauch R (1994) The effects of bicycle accommodations on bicycle/motor vehicle safety and traffic operations. National Technical Information Service, Great Falls, VA.

Wynne GG (1992) National bicycling and walking study; case study 16: a study of bicycle and pedestrian programs in European countries. FHWA-PD-92-037, United States Government Printing Office, Washington DC. 
Table 1. Earlier Studies of Bicycle Route Choice

\begin{tabular}{|c|c|c|c|c|c|c|c|c|c|c|c|c|}
\hline \multirow[b]{2}{*}{ Study } & \multicolumn{3}{|c|}{ Data Source } & \multirow[b]{2}{*}{$\begin{array}{l}\text { Bicycling } \\
\text { purpose } \\
\text { considered }\end{array}$} & \multirow[b]{2}{*}{$\begin{array}{l}\text { Focus of the analysis } \\
\text { (dependent variable) }\end{array}$} & \multirow[b]{2}{*}{$\begin{array}{c}\text { Analysis } \\
\text { framework } \\
\text { employed }\end{array}$} & \multicolumn{6}{|c|}{ Attributes considered } \\
\hline & $\begin{array}{l}\text { Respondents } \\
\text { targeted }\end{array}$ & $\begin{array}{c}\text { Date of } \\
\text { data } \\
\text { collection }\end{array}$ & $\begin{array}{l}\text { Data } \\
\text { elicitation } \\
\text { approach }\end{array}$ & & & & $\begin{array}{c}\text { Individual } \\
\text { and Household }\end{array}$ & $\begin{array}{c}\text { On- } \\
\text { Street } \\
\text { parking }\end{array}$ & $\begin{array}{c}\text { Bicycle } \\
\text { facility type } \\
\text { and } \\
\text { amenities } \\
\end{array}$ & $\begin{array}{c}\text { Roadway } \\
\text { physical } \\
\text { characteristics }\end{array}$ & $\begin{array}{c}\text { Roadway } \\
\text { functional } \\
\text { characteristics }\end{array}$ & $\begin{array}{c}\text { Roadway } \\
\text { operational } \\
\text { characteristics }\end{array}$ \\
\hline \begin{tabular}{c||} 
Antonakos \\
1994
\end{tabular} & $\begin{array}{l}\text { Questionnaire } \\
\text { distributed to } \\
\text { cyclists in } \\
\text { Michigan }\end{array}$ & 1992 & $\begin{array}{c}\text { Revealed } \\
\text { preference } \\
\text { survey (based } \\
\text { on an overall } \\
\text { perception of } \\
\text { bicyclists) }\end{array}$ & Leisure travel & $\begin{array}{l}\text { Environmental and } \\
\text { travel preferences of } \\
\text { bicyclists (bicycling } \\
\text { facilities and on-road } \\
\text { facility characteristics) }\end{array}$ & $\begin{array}{l}\text { Descriptive } \\
\text { analysis }\end{array}$ & $\begin{array}{c}\text { Age, gender, } \\
\text { auto/bicycle } \\
\text { availability, cycling } \\
\text { experience }\end{array}$ & --- & $\begin{array}{l}\text { Bike facility } \\
\text { type and } \\
\text { continuity }\end{array}$ & $\begin{array}{c}\text { Pavement surface, } \\
\text { terrain, scenery, } \\
\text { traffic stops, road } \\
\text { signs }\end{array}$ & $\begin{array}{c}\text { Traffic volume } \\
\text { and speed }\end{array}$ & $\begin{array}{c}\text { Distance, travel } \\
\text { time }\end{array}$ \\
\hline $\begin{array}{l}\text { Aultman- } \\
\text { Hall } 1996\end{array}$ & $\begin{array}{l}\text { Bicyclists in } \\
\text { Ontario, Canada }\end{array}$ & 1993 & $\begin{array}{c}\text { GIS database of } \\
397 \text { commuter } \\
\text { bicycle routes; a } \\
\text { Revealed } \\
\text { Preference } \\
\text { survey } \\
\end{array}$ & Commuting & $\begin{array}{c}\text { Bicycle route } \\
\text { characteristics of } \\
\text { commute routes } \\
\text { (proportion of bicycle } \\
\text { routes with different } \\
\text { route attributes) } \\
\end{array}$ & $\begin{array}{l}\text { Descriptive } \\
\text { analysis }\end{array}$ & Age, gender & --- & Facility type & $\begin{array}{l}\text { Intersection } \\
\text { spacing and } \\
\text { configuration }\end{array}$ & --- & --- \\
\hline $\begin{array}{c}\text { Axhausen } \\
\text { and Smith } \\
1986\end{array}$ & \begin{tabular}{||c|}
2 civil engineering \\
classes and \\
Bombay bicycle \\
club members
\end{tabular} & 1984 & $\begin{array}{l}\text { Stated } \\
\text { Preference } \\
\text { survey }\end{array}$ & All purposes & $\begin{array}{l}\text { Bicycle route choice } \\
\text { (bicycle route) }\end{array}$ & \begin{tabular}{|c|} 
Descriptive \\
analysis and \\
linear \\
regression
\end{tabular} & Cycling experience & --- & Facility type & $\begin{array}{c}\text { Pavement surface, } \\
\text { route surrounding } \\
\text { land-use } \\
\text { characteristics }\end{array}$ & Traffic volume & --- \\
\hline $\begin{array}{c}\text { Bovy and } \\
\text { Bradley } \\
1984\end{array}$ & \begin{tabular}{||c} 
Employees of Delft \\
University, The \\
Netherlands
\end{tabular} & --- & $\begin{array}{l}\text { Stated } \\
\text { Preference } \\
\text { survey }\end{array}$ & Commuting & $\begin{array}{l}\text { Bicycle route choice } \\
\text { (bicycle route) }\end{array}$ & \begin{tabular}{|c|} 
Ordinary \\
least squares, \\
multinomial \\
logit
\end{tabular} & --- & --- & Facility type & Pavement surface & Traffic volume & Travel time \\
\hline $\begin{array}{l}\text { Calgary } \\
1993\end{array}$ & $\begin{array}{l}\text { Bicyclists in } \\
\text { Calgary }\end{array}$ & 1992 & $\begin{array}{l}\text { Revealed } \\
\text { preference } \\
\text { survey }\end{array}$ & Commuting & $\begin{array}{c}\text { To obtain a better } \\
\text { understanding of bicycle } \\
\text { facility needs (bicycle } \\
\text { route characteristics) }\end{array}$ & $\begin{array}{l}\text { Descriptive } \\
\text { analysis }\end{array}$ & --- & --- & $\begin{array}{c}\text { Facility type, } \\
\text { Bicycle } \\
\text { parking } \\
\text { facilities }\end{array}$ & --- & $\begin{array}{c}\text { Traffic volume, } \\
\text { weather }\end{array}$ & --- \\
\hline Davis 1995 & \begin{tabular}{|l} 
Bicyclists in 8 test \\
segments in \\
Atlanta, Georgia
\end{tabular} & 1995 & $\begin{array}{c}\text { Revealed } \\
\text { preference } \\
\text { questionnaires }\end{array}$ & All purposes & $\begin{array}{l}\text { Evaluate the effect of } \\
\text { roadway conditions on } \\
\text { bicycling (route } \\
\text { suitability for bicycling } \\
\text { based on preferences of } \\
\text { bicyclists) }\end{array}$ & $\begin{array}{l}\text { Descriptive } \\
\text { analysis }\end{array}$ & --- & $\begin{array}{l}\text { Presence } \\
\text { of on- } \\
\text { street } \\
\text { parking }\end{array}$ & Facility type & \begin{tabular}{|} 
Pavement surface, \\
Intersection \\
spacing and \\
configuration, \\
route surrounding \\
land-use \\
characteristics, \\
grades \\
\end{tabular} & Traffic speed & --- \\
\hline $\begin{array}{c}\text { Guttenplan } \\
\text { and Patten } \\
1995\end{array}$ & $\begin{array}{c}\text { Bicyclists near } \\
\text { Pinellas Trail, } \\
\text { Florida }\end{array}$ & 1993 & $\begin{array}{l}\text { Revealed } \\
\text { preference } \\
\text { survey }\end{array}$ & All purposes & $\begin{array}{l}\text { Use of bicycle trail for } \\
\text { bicycling (factors } \\
\text { influencing trail use) }\end{array}$ & $\begin{array}{l}\text { Descriptive } \\
\text { analysis }\end{array}$ & --- & --- & $\begin{array}{c}\text { Facility type, } \\
\text { Bicycle } \\
\text { parking } \\
\text { facilities, } \\
\text { showers }\end{array}$ & --- & --- & Travel time \\
\hline $\begin{array}{c}\text { Harris and } \\
\text { Associates } \\
1991\end{array}$ & | Nationwide survey & 1991 & $\begin{array}{l}\text { Revealed } \\
\text { preference } \\
\text { survey }\end{array}$ & All purposes & $\begin{array}{c}\text { Bicycle facilities and } \\
\text { bicyclist characteristics } \\
\text { (bicycle use information } \\
\text { for last year, month and } \\
\text { bicycle facility } \\
\text { characteristics) }\end{array}$ & $\begin{array}{l}\text { Descriptive } \\
\text { analysis }\end{array}$ & --- & --- & Facility type & --- & --- & --- \\
\hline
\end{tabular}


Table 1 (Continued). Earlier Studies of Bicycle Route Choice

\begin{tabular}{|c|c|c|c|c|c|c|c|c|c|c|c|c|}
\hline \multirow[b]{2}{*}{ Study } & \multicolumn{3}{|c|}{ Data Source } & \multirow[b]{2}{*}{\begin{tabular}{|l|} 
Bicycling \\
purposes \\
considered
\end{tabular}} & \multirow[b]{2}{*}{$\begin{array}{l}\text { Focus of the analysis } \\
\text { (dependent variable) }\end{array}$} & \multirow[b]{2}{*}{$\begin{array}{c}\text { Analysis } \\
\text { framework } \\
\text { employed }\end{array}$} & \multicolumn{6}{|c|}{ Attributes considered } \\
\hline & $\begin{array}{l}\text { Respondents } \\
\text { targeted }\end{array}$ & $\begin{array}{c}\text { Date of } \\
\text { data } \\
\text { collection }\end{array}$ & $\begin{array}{l}\text { Data } \\
\text { elicitation } \\
\text { approach }\end{array}$ & & & & $\begin{array}{c}\text { Individual } \\
\text { and Household }\end{array}$ & $\begin{array}{c}\text { On- } \\
\text { Street } \\
\text { parking }\end{array}$ & $\begin{array}{c}\text { Bicycle } \\
\text { facility type } \\
\text { and } \\
\text { amenities }\end{array}$ & $\begin{array}{c}\text { Roadway } \\
\text { physical } \\
\text { characteristics }\end{array}$ & $\begin{array}{c}\text { Roadway } \\
\text { functional } \\
\text { characteristics }\end{array}$ & $\begin{array}{c}\text { Roadway } \\
\text { operational } \\
\text { characteristics }\end{array}$ \\
\hline \begin{tabular}{|} 
Hopkinson \\
and \\
Wardman \\
1996
\end{tabular} & \begin{tabular}{||c|} 
Current and \\
potential bicyclists \\
in an urban \\
transport corridor \\
in Bradford, UK \\
\end{tabular} & 1994 & $\begin{array}{l}\text { Household and } \\
\text { Stated } \\
\text { preference } \\
\text { survey }\end{array}$ & All purposes & $\begin{array}{l}\text { Estimating the demand } \\
\text { for and valuation of } \\
\text { cycling facilities. } \\
\text { (bicycle route choice) }\end{array}$ & $\begin{array}{l}\text { Descriptive } \\
\text { analysis and } \\
\text { logit model }\end{array}$ & \begin{tabular}{|c|} 
Age, gender, \\
auto/bicycle \\
availability, cycling \\
experience, reasons \\
of cycling \\
\end{tabular} & --- & Facility type & --- & --- & $\begin{array}{l}\text { Travel time, } \\
\text { travel cost }\end{array}$ \\
\hline $\begin{array}{l}\text { Hunt and } \\
\text { Abraham } \\
2006\end{array}$ & $\begin{array}{l}\text { Bicyclists in } \\
\text { Edmonton, } \\
\text { Canada }\end{array}$ & 1994 & $\begin{array}{l}\text { Stated } \\
\text { preference } \\
\text { survey }\end{array}$ & $\begin{array}{l}\text { Non- } \\
\text { recreational } \\
\text { travel } \\
\text { purpose }\end{array}$ & $\begin{array}{l}\text { Factors influencing } \\
\text { bicycle use (bicycle } \\
\text { route choice) }\end{array}$ & $\begin{array}{l}\text { Multinomial } \\
\text { logit model }\end{array}$ & $\begin{array}{l}\text { Age, bicycling } \\
\text { experience }\end{array}$ & --- & $\begin{array}{c}\text { Facility type, } \\
\text { bicycle } \\
\text { parking, } \\
\text { showers }\end{array}$ & --- & Traffic volume & Travel time \\
\hline $\begin{array}{l}\text { Landis et } \\
\text { al. } 1997\end{array}$ & \begin{tabular}{|c|} 
A test course \\
located in Tampa, \\
Florida
\end{tabular} & 1997 & $\begin{array}{l}\text { Experimental } \\
\text { data from test } \\
\text { course }\end{array}$ & \begin{tabular}{|l} 
Experiment \\
study with \\
all \\
participants \\
of varied \\
cycling \\
experience
\end{tabular} & $\begin{array}{l}\text { Develop a bicycle level } \\
\text { of service variable } \\
\text { (quality of service) }\end{array}$ & $\begin{array}{l}\text { Regression } \\
\text { analysis }\end{array}$ & --- & --- & Facility type & $\begin{array}{c}\text { Pavement surface, } \\
\text { route surrounding } \\
\text { land-use } \\
\text { characteristics }\end{array}$ & $\begin{array}{l}\text { Traffic speed, } \\
\text { traffic volume }\end{array}$ & --- \\
\hline $\begin{array}{c}\text { Lott et al. } \\
1978\end{array}$ & \begin{tabular}{|c|} 
Bicyclists in \\
Davis, California
\end{tabular} & 1974 & $\begin{array}{l}\text { Revealed } \\
\text { preference data } \\
\text { before and after } \\
\text { the new facility } \\
\text { construction }\end{array}$ & All purposes & $\begin{array}{l}\text { Attitudes of bicyclists } \\
\text { toward a new bicycle } \\
\text { facility (bicycle route } \\
\text { choice) }\end{array}$ & $\begin{array}{l}\text { Descriptive } \\
\text { analysis }\end{array}$ & --- & --- & Facility type & --- & --- & Safety concerns \\
\hline $\begin{array}{c}\text { Ortúzar et } \\
\text { al. } 2000\end{array}$ & \begin{tabular}{|c} 
Potential bicycle \\
users in Santiago, \\
Chile
\end{tabular} & 1999 & $\begin{array}{l}\text { Household and } \\
\text { Stated } \\
\text { preference } \\
\text { survey }\end{array}$ & All purposes & $\begin{array}{c}\text { Identifying the factors } \\
\text { conditioning bicycling } \\
\text { (choice of cycling, mode } \\
\text { choice) }\end{array}$ & Logit model & \begin{tabular}{|} 
Age, gender, \\
household size and \\
income, auto/bicycle \\
ownership, \\
education/ \\
employment level, \\
frequency/reason of \\
bicycling, weather \\
\end{tabular} & & Facility type & --- & --- & $\begin{array}{l}\text { Travel time, } \\
\text { travel cost, } \\
\text { accessibility to } \\
\text { public transport }\end{array}$ \\
\hline $\begin{array}{c}\text { Sacks } \\
1994\end{array}$ & $\begin{array}{l}\text { Bicyclists on } \\
\text { greenways in } \\
\text { Baltimore }\end{array}$ & 1993 & $\begin{array}{l}\text { Revealed } \\
\text { preference } \\
\text { questionnaires }\end{array}$ & All purposes & $\begin{array}{l}\text { Examining the use of } \\
\text { greenways for bicycling } \\
\text { (bicyclist and bicycle } \\
\text { facility characteristics) }\end{array}$ & $\begin{array}{l}\text { Descriptive } \\
\text { analysis }\end{array}$ & $\begin{array}{c}\text { Age, gender, vehicle } \\
\text { ownership, work } \\
\text { flexibility, personal } \\
\text { security }\end{array}$ & --- & \begin{tabular}{|l} 
Facility type, \\
continuity, \\
bicycle \\
parking, \\
showers \\
\end{tabular} & --- & --- & --- \\
\hline $\begin{array}{l}\text { Stinson } \\
\text { and Bhat } \\
2003\end{array}$ & $\begin{array}{l}\text { Commuter } \\
\text { bicyclists in the } \\
\text { US }\end{array}$ & 2002 & $\begin{array}{l}\text { Web based } \\
\text { stated } \\
\text { preference } \\
\text { survey }\end{array}$ & Commuting & $\begin{array}{c}\text { Factors affecting } \\
\text { commuter bicyclist route } \\
\text { choice (bicycle route } \\
\text { choice) }\end{array}$ & $\begin{array}{l}\text { Multinomial } \\
\text { logit model }\end{array}$ & $\begin{array}{l}\text { Age, gender and } \\
\text { income }\end{array}$ & $\begin{array}{l}\text { Presence } \\
\text { of } \\
\text { parallel } \\
\text { parking }\end{array}$ & $\begin{array}{c}\text { Facility type, } \\
\text { continuity }\end{array}$ & $\begin{array}{c}\text { Roadway class, } \\
\text { pavement surface, } \\
\text { bridge type, terrain } \\
\text { grade, traffic stops, } \\
\text { red lights and cross } \\
\text { streets }\end{array}$ & --- & --- \\
\hline $\begin{array}{c}\text { Tilahun et } \\
\text { al. } 2007\end{array}$ & \begin{tabular}{||c|} 
Employees of the \\
University of \\
Minnesota, \\
excluding students \\
and faculty
\end{tabular} & 2004 & $\begin{array}{l}\text { Adaptive Stated } \\
\text { Preference } \\
\text { Survey }\end{array}$ & Commuting & $\begin{array}{l}\text { To understand the } \\
\text { tradeoffs between } \\
\text { different bicycling } \\
\text { facility features } \\
\text { (bicycle route choice) }\end{array}$ & $\begin{array}{l}\text { Binomial } \\
\text { logit and } \\
\text { linear utility } \\
\text { models }\end{array}$ & $\begin{array}{c}\text { Age, gender, } \\
\text { bicycling season; } \\
\text { household size, } \\
\text { household income }\end{array}$ & $\begin{array}{l}\text { Presence } \\
\text { of side- } \\
\text { street } \\
\text { parking }\end{array}$ & Facility type & --- & --- & Travel time \\
\hline
\end{tabular}


Table 2. Bicycle Route Attribute Levels Selected for the SP Experiments

\begin{tabular}{|c|c|c|c|c|}
\hline $\begin{array}{l}\text { Attribute } \\
\text { Category }\end{array}$ & Attribute & Attribute & \multicolumn{2}{|r|}{ Attribute levels } \\
\hline \multirow{4}{*}{$\begin{array}{l}\text { On-street } \\
\text { parking }\end{array}$} & Parking type & $\begin{array}{l}\text { The parking configuration on a } \\
\text { shared roadway (for instance, } \\
\text { parallel parking) }\end{array}$ & \multicolumn{2}{|l|}{$\begin{array}{l}\text { 1. None } \\
\text { 2. Parallel } \\
\text { 3. Angle }\end{array}$} \\
\hline & $\begin{array}{l}\text { Parking turnover } \\
\text { rate }\end{array}$ & $\begin{array}{l}\text { The likelihood of a cyclist } \\
\text { encountering a car leaving a parking } \\
\text { spot along the route }\end{array}$ & \multicolumn{2}{|c|}{$\begin{array}{l}\text { 1. Low (A cyclist very occasionally encounters a car leaving a parking spot) } \\
\text { 2. Moderate (A cyclist sometimes encounters a car leaving a parking spot) } \\
\text { 3. High (A cyclist usually encounters a vehicle leaving a parking spot) }\end{array}$} \\
\hline & $\begin{array}{l}\text { Length of } \\
\text { parking area }\end{array}$ & $\begin{array}{l}\text { The length of the motor vehicle } \\
\text { parking facility on the bicycle route }\end{array}$ & \multicolumn{2}{|l|}{$\begin{array}{l}\text { 1. Short }(1 / 2-1 \text { city block }) \\
\text { 2. Moderate }(2-4 \text { city blocks }) \\
\text { 3. Long ( } 5-7 \text { city blocks })\end{array}$} \\
\hline & $\begin{array}{l}\text { Parking } \\
\text { occupancy rate }\end{array}$ & $\begin{array}{l}\text { The percentage of parking spots } \\
\text { occupied in a motor vehicle parking } \\
\text { facility }\end{array}$ & \multicolumn{2}{|l|}{$\begin{array}{l}\text { 1. Low }(0-25 \%) \\
\text { 2. Moderate }(26-75 \%) \\
\text { 3. High }(76-100 \%)\end{array}$} \\
\hline \multirow{2}{*}{ Bikeway facility } & $\begin{array}{l}\text { Facility } \\
\text { continuity }\end{array}$ & $\begin{array}{l}\text { A bicycle route is considered to be } \\
\text { continuous if the whole route has a } \\
\text { bicycle facility (a bike lane or wide } \\
\text { outside lane) and discontinuous } \\
\text { otherwise }\end{array}$ & \multicolumn{2}{|c|}{$\begin{array}{l}\text { 1. continuous - the whole route has a bicycle facility } \\
\text { 2. discontinuous - the whole route does not have a bicycle facility }\end{array}$} \\
\hline & $\begin{array}{l}\text { Bikeway facility } \\
\text { type and width }\end{array}$ & $\begin{array}{l}\text { The width of the bike lane when it is } \\
\text { present; otherwise the roadway } \\
\text { width }\end{array}$ & \multicolumn{2}{|c|}{$\begin{array}{l}\text { 1. A bicycle lane } 1.5 \text { bicycle width wide (or } 3.75 \text { feet wide) } \\
\text { 2. A bicycle lane } 2.5 \text { bicycle width wide (or } 6.25 \text { feet wide) } \\
\text { 3. No bicycle lane and a } 1.5 \text { car width }(10.5 \text { feet) wide outside lane } \\
\text { 4. No bicycle lane and a } 2.0 \text { car width }(14.0 \text { feet) wide outside lane } \\
\text { 5. No bicycle lane and a } 2.5 \text { car width ( } 17.5 \text { feet) wide outside lane }\end{array}$} \\
\hline Roadway & Roadway grade & $\begin{array}{l}\text { The terrain grade of the bicycle } \\
\text { route (for instance, moderate hills) }\end{array}$ & \multicolumn{2}{|l|}{$\begin{array}{l}\text { 1. Flat - no hills } \\
\text { 2. Some moderate hills } \\
\text { 3. Some steep hills }\end{array}$} \\
\hline characteristics & $\begin{array}{l}\text { Number of stop } \\
\text { signs, red lights } \\
\text { and cross streets }\end{array}$ & $\begin{array}{l}\text { Number of stop signs and red lights } \\
\text { encountered on the bicycle route }\end{array}$ & \multicolumn{2}{|l|}{$\begin{array}{ll}\text { 1. } & 1-2 \\
\text { 2. } & 3-5 \\
\text { 3. } & \text { More than } 5\end{array}$} \\
\hline \multirow{2}{*}{$\begin{array}{c}\text { Roadway } \\
\text { functional } \\
\text { characteristics }\end{array}$} & Traffic volume & $\begin{array}{l}\text { Traffic volume on the roadways } \\
\text { encountered on the bicycle route }\end{array}$ & \multicolumn{2}{|l|}{$\begin{array}{l}\text { 1. Light } \\
\text { 2. Moderate } \\
\text { 3. Heavy }\end{array}$} \\
\hline & Speed limit & $\begin{array}{l}\text { Speed limit of the roadways } \\
\text { encountered on the bicycle route }\end{array}$ & \multicolumn{2}{|l|}{$\begin{array}{l}\text { 1. Less than } 20 \mathrm{mph} \\
\text { 2. } 20-35 \mathrm{mph} \\
\text { 3. More than } 35 \mathrm{mph}\end{array}$} \\
\hline $\begin{array}{c}\text { Roadway } \\
\text { operational } \\
\text { characteristics }\end{array}$ & Travel time & $\begin{array}{l}\text { Travel time to destination (for } \\
\text { commuting bicyclists only) }\end{array}$ & $\begin{array}{l}\text { 1. Stated travel time for commute }-y \\
\text { 2. Stated travel time for commute }-x \\
\text { 3. Stated travel time for commute } \\
\text { 4. Stated travel time for commute }+x \\
\text { 5. Stated travel time for commute }+y\end{array}$ & $\begin{array}{l}\text { If stated travel time } \leq 25 \text { minutes } x=5, y=10 ; \\
\text { If stated travel time }>25 \text { and } \leq 45 \text { minutes } x=5, y=15 \text {; } \\
\text { If stated travel time }>45 \text { minutes } x=10, y=20 ; \\
\text { The travel time obtained after the operations is rounded } \\
\text { off to the nearest multiple of } 5\end{array}$ \\
\hline
\end{tabular}


Table 3. Bicycle Route Choice Model Results with Interaction Effects

\begin{tabular}{|c|c|c|c|c|}
\hline & Attribute & $\begin{array}{l}\text { Attribute Level and } \\
\text { Interactions }\end{array}$ & Coefficient & t-statistics \\
\hline \multirow[t]{4}{*}{$\begin{array}{l}\text { On-street } \\
\text { Parking } \\
\text { Characteristics }\end{array}$} & $\begin{array}{l}\text { Parking type } \\
\text { (base: absence of parking) }\end{array}$ & $\begin{array}{l}\text { Parallel parking permitted } \\
\text { Male } \\
\text { Age } \\
\quad 18-24 \text { years } \\
\text { Long commute distance } \\
5 \text { miles or longer } \\
\text { Angle parking permitted } \\
\text { Male } \\
\text { Long commute distance } \\
5 \text { miles or longer }\end{array}$ & $\begin{array}{l}-0.422 \\
-0.125 \\
0.281 \\
-0.230 \\
-0.190 \\
-0.125 \\
-0.230\end{array}$ & $\begin{array}{l}-4.35 \\
-1.77 \\
2.60 \\
-2.45 \\
-2.98 \\
-1.77 \\
-2.45\end{array}$ \\
\hline & $\begin{array}{l}\text { Parking turnover rate } \\
\text { (base: low parking turnover) }\end{array}$ & $\begin{array}{l}\text { Moderate } \\
\text { High } \\
\quad \text { Female }\end{array}$ & $\begin{array}{r}-0.264 \\
-0.490 \\
-0.401\end{array}$ & $\begin{array}{l}-3.15 \\
-3.09 \\
-2.22\end{array}$ \\
\hline & $\begin{array}{l}\text { Length of parking area } \\
\text { (base: short }-1 / 2-1 \text { city block) }\end{array}$ & $\begin{array}{l}\text { Moderate (2-4 city blocks) } \\
\text { Long (5-7 city blocks) }\end{array}$ & $\begin{array}{l}-0.564 \\
-0.631\end{array}$ & $\begin{array}{l}-4.37 \\
-5.30\end{array}$ \\
\hline & $\begin{array}{l}\text { Parking occupancy rate } \\
\text { (base: low }-0-25 \% \text { ) }\end{array}$ & $\begin{array}{l}\text { Moderate }(26-75 \%) \\
\text { High (76-100\%) }\end{array}$ & $\begin{array}{l}-0.290 \\
-0.959\end{array}$ & $\begin{array}{l}-2.29 \\
-7.04\end{array}$ \\
\hline \multirow{2}{*}{$\begin{array}{l}\text { Bicycle Facility } \\
\text { Characteristics }\end{array}$} & $\begin{array}{l}\text { Bikeway facility width/type } \\
\text { (base: bicycle lane " } 3.75 \mathrm{ft}- \\
6.25 \mathrm{ft} \text { ") }\end{array}$ & $\begin{array}{l}\text { No bicycle lane and a } 10.5 \text { feet } \\
\text { wide outside lane } \\
\text { No bicycle lane and } a \geq 14 \text { feet } \\
\text { wide outside lane }\end{array}$ & $\begin{array}{l}0.089 \\
0.097\end{array}$ & $\begin{array}{l}1.56 \\
2.23\end{array}$ \\
\hline & $\begin{array}{l}\text { Continuous bicycle facility } \\
\text { (base: discontinuous) }\end{array}$ & $\begin{array}{l}\text { Continuous facility } \\
\text { Long commute distance } \\
5 \text { miles or longer } \\
\text { Parallel parking permitted }\end{array}$ & $\begin{array}{r}0.859 \\
0.322 \\
-0.249\end{array}$ & $\begin{array}{r}9.72 \\
2.44 \\
-3.08\end{array}$ \\
\hline $\begin{array}{l}\text { Roadway } \\
\text { Physical } \\
\text { Characteristics }\end{array}$ & $\begin{array}{l}\text { Terrain grade } \\
\text { (base: flat-no hills) }\end{array}$ & $\begin{array}{l}\text { Moderate Hills } \\
\text { Non-commuting bicycling } \\
\text { Standard deviation } \\
\text { Steep Hills } \\
\text { Male } \\
\text { Non-commuting bicycling } \\
\text { Standard deviation }\end{array}$ & $\begin{array}{r}0.226 \\
0.376 \\
0.683 \\
-0.353 \\
0.447 \\
0.376 \\
0.683\end{array}$ & $\begin{array}{r}1.68 \\
2.59 \\
7.06 \\
-2.37 \\
5.01 \\
2.59 \\
7.06\end{array}$ \\
\hline
\end{tabular}


Table 3 (Continued). Bicycle Route Choice Model Results with Interaction Effects

\begin{tabular}{|c|c|c|c|c|}
\hline & Attribute & Attribute Level and Interactions & Coefficient & t-statistics \\
\hline $\begin{array}{l}\text { Roadway } \\
\text { Physical } \\
\text { Characteristics }\end{array}$ & $\begin{array}{l}\text { \# Stop signs, red lights } \\
\text { and cross streets } \\
\text { (base: low- } 1-2 \text { ) }\end{array}$ & $\begin{array}{l}\text { Moderate (3-5) } \\
\quad \text { Male } \\
\text { High (more than 5) } \\
\text { Male } \\
\text { Experience in bicycling }\end{array}$ & $\begin{array}{r}-0.513 \\
0.202 \\
-1.702 \\
0.190 \\
0.869\end{array}$ & $\begin{array}{r}-6.22 \\
2.04 \\
-6.46 \\
1.83 \\
3.43\end{array}$ \\
\hline \multirow[t]{2}{*}{$\begin{array}{l}\text { Roadway } \\
\text { Functional } \\
\text { Characteristics }\end{array}$} & $\begin{array}{l}\text { Traffic volume } \\
\text { (base: light) }\end{array}$ & $\begin{array}{l}\text { Moderate } \\
\text { Male } \\
\text { Non-commuting bicycling } \\
\text { Standard deviation } \\
\text { Heavy } \\
\text { Male } \\
\text { Non-commuting bicycling } \\
\text { Long commute distance } \\
\quad 5 \text { miles or longer } \\
\text { Discontinuous bicycle facility } \\
\text { Standard deviation }\end{array}$ & $\begin{array}{r}-0.726 \\
-0.239 \\
0.390 \\
1.041 \\
-2.128 \\
-0.239 \\
0.390 \\
-0.493 \\
-0.512 \\
1.041\end{array}$ & $\begin{array}{r}-5.99 \\
-2.15 \\
3.73 \\
15.58 \\
-16.58 \\
-2.15 \\
3.73 \\
-3.08 \\
-2.93 \\
15.58\end{array}$ \\
\hline & $\begin{array}{l}\text { Speed limit } \\
\text { (base: low- less than } 20 \\
\text { mph) }\end{array}$ & $\begin{array}{l}\text { Moderate (20-35 mph) } \\
\text { Experience in bicycling } \\
\text { Long commute distance } \\
5 \text { miles or longer } \\
\text { High (more than } 35 \mathrm{mph}) \\
\text { Experience in bicycling } \\
\text { Long commute distance } \\
5 \text { miles or longer }\end{array}$ & $\begin{array}{r}-0.742 \\
0.605 \\
0.455 \\
-1.559 \\
0.642 \\
0.423\end{array}$ & $\begin{array}{l}-3.00 \\
2.36 \\
3.29 \\
-6.65 \\
2.65 \\
3.05\end{array}$ \\
\hline $\begin{array}{l}\text { Roadway } \\
\text { Operational } \\
\text { Characteristics }\end{array}$ & Travel time & $\begin{array}{l}\text { Travel time (minutes) } \\
\text { Age } \\
18-34 \text { years } \\
\text { Standard deviation }\end{array}$ & $\begin{array}{r}-0.068 \\
-0.052 \\
0.081\end{array}$ & $\begin{array}{l}-7.21 \\
-4.07 \\
10.66\end{array}$ \\
\hline
\end{tabular}


Table 4. Time and Money-Based Trade-offs of Route Attributes

\begin{tabular}{|c|c|c|c|c|c|c|}
\hline & \multirow{2}{*}{ Attribute } & \multirow{2}{*}{ Attribute Level } & \multicolumn{2}{|c|}{ Time Value (in min.) } & \multicolumn{2}{|c|}{ Money Value (in \$) } \\
\hline & & & $\begin{array}{c}\begin{array}{c}\text { Short-commute } \\
\text { distance }\end{array} \\
\end{array}$ & $\begin{array}{c}\text { Long-commute } \\
\text { distance }\end{array}$ & $\begin{array}{c}\begin{array}{c}\text { Short-commute } \\
\text { distance }\end{array} \\
\end{array}$ & $\begin{array}{c}\text { Long-commute } \\
\text { distance }\end{array}$ \\
\hline \multirow{8}{*}{$\begin{array}{l}\text { On-street } \\
\text { Parking }\end{array}$} & \multirow{2}{*}{ Parking type } & Parallel parking permitted & 6.21 & 9.59 & 1.26 & 1.95 \\
\hline & & Angle parking permitted & 2.79 & 6.18 & 0.57 & 1.25 \\
\hline & \multirow{2}{*}{$\begin{array}{l}\text { Parking } \\
\text { turnover rate }\end{array}$} & Moderate & 3.88 & 3.88 & 0.79 & 0.79 \\
\hline & & High & 13.10 & 13.10 & 2.66 & 2.66 \\
\hline & \multirow{2}{*}{$\begin{array}{l}\text { Length of } \\
\text { parking area }\end{array}$} & Moderate (2-4 city blocks) & 8.29 & 8.29 & 1.69 & 1.69 \\
\hline & & Long (5-7 city blocks) & 9.28 & 9.28 & 1.89 & 1.89 \\
\hline & \multirow{2}{*}{$\begin{array}{l}\text { Parking } \\
\text { occupancy rate }\end{array}$} & Moderate $(26-75 \%)$ & 4.26 & 4.26 & 0.87 & 0.87 \\
\hline & & High $(76-100 \%)$ & 14.10 & 14.10 & 2.87 & 2.87 \\
\hline \multirow{3}{*}{ Bicycle Facility } & \multirow{2}{*}{$\begin{array}{l}\text { Bikeway } \\
\text { width/type }\end{array}$} & $\begin{array}{l}\text { No bicycle lane and a } 10.5 \\
\text { feet wide outside lanewidths }\end{array}$ & -1.31 & -1.31 & -0.27 & -0.27 \\
\hline & & $\begin{array}{l}\text { No bicycle lane and } a \geq 14 \\
\text { feet wide outside lanewidths }\end{array}$ & -1.43 & -1.43 & -0.29 & -0.29 \\
\hline & $\begin{array}{l}\text { Continuous } \\
\text { bicycle facility }\end{array}$ & Continuous & -12.63 & -17.37 & -2.57 & -3.53 \\
\hline \multirow{4}{*}{$\begin{array}{c}\text { Roadway } \\
\text { Physical } \\
\text { Characteristics }\end{array}$} & \multirow{2}{*}{ Terrain grade } & Moderate hills & -3.32 & -3.32 & -0.68 & -0.68 \\
\hline & & Steep hills & 5.19 & 5.19 & 1.05 & 1.05 \\
\hline & \multirow{2}{*}{$\begin{array}{l}\text { \# Stop signs, red } \\
\text { lights and cross } \\
\text { streets }\end{array}$} & Moderate (3-5) & 7.54 & 7.54 & 1.53 & 1.53 \\
\hline & & High (more than 5) & 25.03 & 25.03 & 5.09 & 5.09 \\
\hline \multirow{4}{*}{$\begin{array}{c}\text { Roadway } \\
\text { Functional } \\
\text { Characteristics }\end{array}$} & \multirow{2}{*}{ Traffic volume } & Moderate & 10.68 & 10.68 & 2.17 & 2.17 \\
\hline & & Heavy & 31.29 & 38.54 & 6.36 & 7.83 \\
\hline & \multirow{2}{*}{ Speed limit } & Moderate $(20-35 \mathrm{mph})$ & 10.91 & 4.22 & 2.22 & 0.86 \\
\hline & & High (more than $35 \mathrm{mph}$ ) & 22.93 & 16.71 & 4.66 & 3.39 \\
\hline
\end{tabular}

\footnotetext{
${ }^{5}$ The money value of time, which is $12.19 \$ / \mathrm{hr}$, was obtained from a research conducted by Bhat and Sardesai (2006)
} 